Number 5

\title{
PENGARUH VARIASI SUHU PENYIMPANAN TERHADAP VITALITAS SPERMA
}

\author{
Ida Bagus Teja ${ }^{1}$, IG Sudarmanto ${ }^{2}$, IW Merta ${ }^{3}$
}

\begin{abstract}
Background.Sperm is very sensitive to changes in temperature, this can cause changing the characteristics of spermatozoa. To perform sperm analysis it is necessary to determine the optimal storage temperature to keep the characteristic of sperm samples remain representative.

Objective.The purpose of this study to determine the effect of variation in storage temperature on sperm vitality, in order to determine the optimal storage temperature of sperm samples when delay of examination.

Methods. In this study we used microscopic method with supravitalstainting using 0,5\% eosin staint. Dead spermatozoa will be stained by eosin and live spermatozoa will not be stained by eosin.The study was conducted on 8 subject of the Department of Health Analyst Poltekkes Denpasar that selected by randomly simpling with One Group pretest-posttest design. The measured variable is the value of sperm vitality before and after treatment.

Results :Analysis with T-Paired test showed significant difference before and after treatment ( $p<0,05)$ before treatment $84,687 \% \pm 3,796$, to $78.725 \% \pm 3.809$ at $4 o C$, at temperature $25 \circ \mathrm{C}$ is $82,7875 \% \pm 3,588$, and at $37^{\circ} \mathrm{C}$ is $70 \% \pm 4,152$.

Conclusion.From the results of research that has been done, it can be concluded that the decrease in sperm vitality is obtained at least 25oC storage temperature for 1 hour and the most decrease obtained at storage at 37oC for 1 hour.
\end{abstract}

Keywords:Sperm vitality, spermatozoa

\section{PENDAHULUAN}

Infertilitasdapatterjadipadapriadan wanita.Infertilitaspriaditemukanpada $50 \%$ pasanganinfertil.Sekitar $15 \%$ daripasangan infertile

tersebutmencaripengobatanuntukmasalahi nfertilitas.Meskipunakhirnyakurangdari $5 \%$ pasanganinfertil, tetaptidakmemperolehketurunan.Infertilita ssuatupasangandapatdijumpaisecarabersa maanbaikpadapriadanwanita.Menurunnyak esuburanpriadapatdisebabkankarenakelain anurogenital bawaan, kelainan genetic maupunkelainandidapatsepertiinfeksikelen jarseksaksesoris, varicocele, gangguanendokrin, dan factor imunologi ${ }^{1}$.Kualitasspermamerupakansuat uhal yang sangatpentingbagiuntukdapatmemperolehk eturunan.Kualitasspermadapatdianalisissec aramakroskopisdanmikroskopis.Secarama kroskopisspermadiperiksadenganmenganal isis volume sampelsperma, $\mathrm{pH}$ sperma (7,2-7,8), bausperma, warnasperma, danvisikositassperma ${ }^{2}$. 
Selspermasangat sensitive terhadapperubahansuhu di sekitarnya, suhu yang

terlampaurendahdapatmenurunkanmotilita ssperma,

sehinggaselspermaterlihatkurangaktifdanti dak prima.Sedangkansuhu yang terlampautinggiakanmenyebabkanrusakny a

protein

pelindungselspermasehinggavitalitassperm aakanrendah. MenurutpenelitianNilani ${ }^{3}$, penyimpananspermapadasuhu $\quad 4-8^{\circ} \mathrm{C}$ dapatmenurunkanmotilitasdanvitalitassper masecarasignifikansetelah 24 jam penyimpanan.

Vitalitasspermamerupakanhal yang pentingdalam proses pembuahan, semakintinggivitalitasspermamaka proses pembuahansemakincepatterjadikarenasedi kitspermayang mati ${ }^{4}$.

Menurutpenelitian Mohamed (2014) $)^{1}$,

suhusaatliquefasisangatberpengaruhterhad apvitalitassperma,

karenadapatmerubahkarakteristiksperma.P erubahansuhusaatliquefasimenyebabkan protein

selspermamudahrusak.Berdasarkansimpula npenelitiantersebut, suhu yang optimum saatliquefasiadalah

$25^{\circ} \mathrm{C}$.Dimanaspermamenunjukanmorfologi , motilitas yang normaldanvitalitas yang tinggi.
Berdasarkanhasilujipendahuluan yang dilakukanolehpeneliti, diperolehhasilvitalitasspermadenganpenur unan paling sedikitdarisperma yang belumdilakukanintervensiadalahpadasuhu $25^{\circ} \mathrm{C}$ danpenurunanterbesarterjadipadasuhupeny impanan $4^{\circ} \mathrm{C}$.

Berdasarkanuraian yang telahdipaparkan di atasmakapenelititertarikuntukmenelitikuali tasspermadenganmembandingkanhasilVita litasspermadenganperbedaansuhusaatpenyi mpananyaitu $\quad 4^{\circ} \mathrm{C}, \quad 25^{\circ} \mathrm{C}$ dan $37^{\circ} \mathrm{C}$ untukmengetahuisuhu yang optimal yang dapatdigunakandalampenyimpanansperma selamapenundaanpemeriksaanberlangsung.

\section{METODE}

Jenispenelitian yang digunakanadalahPraeksperiment5Penelitianinibertujuanuntukm engetahuidayatahanspermaterhadapvariasi suhupenyimpanandengancarapengecatansu pravitaldanpemeriksaansecaramikroskopik

Populasidalampenelitianini yang menjadipopulasiadalahseluruhMahasiswaJ urusan

\section{DIII}

AnalisKesehatanPoltekkesKemenkes

Denpasar, yang berjumlah 26 orang.Besarsampel yang digunakandalampenelitianiniadalah $\quad 8$ sampel, dimanamasing- 
masingsampelmemiliki

kelompokeksperimen.Sehingga total data yang diperolehadalah 32 data.

Jalannyapenelitianinidimulaidenga ntahappretesdipipet $50 \mu 1$ sampelspermadanditeteskanpadaobjekglas danditambahkan $50 \mu 1$ eosine $0,5 \%$ dandi homogeny kankemudianditutupdengan cover glass. Dibiarkanselama 30 detikdandibacadibawahmikroskopdenganp embesaran40x. Selspermamati, kepalaatauseluruhtubuhnyaakanterwarnaie osinesehinggaberwarna pink ataumerah. Sedangkansperma yang hiduptidakakanterwarnaieosine, sehinggaterlihatbeningtidakberwarna.Setel ahdilakukanpemeriksaanvitalitasspermasa mpeldipisahkankedalam 3 port. Pot 1 disimpan di refrigerator padasuhu $4{ }^{\circ} \mathrm{C}$, port 2 disimpanpadaruangandengansuhu $25^{\circ} \mathrm{C}$, dan port 3 disimpanpada incubator dengansuhu $37^{\circ} \mathrm{C}$ masing-masingselama 1 jam,

kemudianketigasampeltersebutdilakukanpe meriksaanvitalitasspermadenganuji statistic t paired.

\section{HASIL DAN PEMBAHASAN}

HASIL

Padapenelitianinidapatdilihat data nilaivitalitasspermapadakelompoksebelum perlakuan, perlakuanpadasuhu $4^{\circ} \mathrm{C}, 25^{\circ} \mathrm{C}$ dan $37^{\circ} \mathrm{C}$ padatabel 1.

Tabel 1.NilaiVitalitasSpermaSebelumdanSesudahPelakuan

\begin{tabular}{|c|c|}
\hline KelompokPerlakuan & Rata-rata vitalitassperma (\%) SD \\
\hline Sebelumperlakuan & $84,69 \pm 3,80$ \\
\hline Penyimpanansuhu $4^{\circ} \mathrm{C}$ & $78,73 \% \pm 3,81$ \\
\hline Penyimpanansuhu $25^{\circ} \mathrm{C}$ & $82,79 \% \pm 3,59$ \\
\hline Penyimpanansuhu $37^{\circ} \mathrm{C}$ & $70,00 \pm 4,15$ \\
\hline
\end{tabular}

Tabel

diatasnilaivitalitasspermasebelumperlakuk anmemilikinilaitertinggidibandingkandeng ankelompokperlakuanpadasuhu yang
bervariasi.Data

hasilujiT-Paired perbandingannilaivitalitasspermasebelumd ansesudahperlakuandapatdilihatpadatabel 2 , 3 dan 4

Tabel 2

VitalitasSpermaSebelum Dan SesudahDisimpanPadaSuhu $4^{\circ} \mathrm{C}$ Selama 1 Jam

\begin{tabular}{|c|c|c|}
\hline \multirow{2}{*}{ Kelompokperbandingan } & $\begin{array}{c}\text { Vitalitassperma (\%) } \\
\text { SD }\end{array}$ & Nilaip \\
\hline Sebelumperlakuan & $84,69 \pm 3,80$ & 0,000 \\
\hline
\end{tabular}

Meditory | ISSN Online : 2549-1520, ISSN Cetak : 2338 - 1159, Vol. 5, No. 2, Desember 2017103 HIm. 101 - 106, http://ejournal.poltekkes-denpasar.ac.id 


\begin{tabular}{|c|c|c|}
\hline Perlakuan & $78,73 \% \pm 3,81$ & \\
\hline
\end{tabular}

Tabel diatas esudahdisimpanpadasuhu $\quad 4^{\circ} \mathrm{C}$ selama 1 dataantaranilaivitalitasspermasebelumdans jam.

Tabel3

VitalitasSpermaSebelum Dan SesudahDisimpanPadaSuhu $25^{\circ} \mathrm{C}$ Selama 1 Jam

\begin{tabular}{|c|c|c|}
\hline Kelompokperbandingan & $\begin{array}{c}\text { Vitalitassperma (\%) } \\
\text { SD }\end{array}$ & Nilaip \\
\hline Sebelumperlakuan & $84,69 \pm 3,80$ & \multirow{2}{*}{0,000} \\
\hline Perlakuan & $82,79 \% \pm 3,59$ & \\
\hline
\end{tabular}

Tabel diatas esudahdisimpanpadasuhu $25^{\circ} \mathrm{C}$ selama 1 dataantaranilaivitalitasspermasebelumdans jam.

Tabel4

Data PerbandinganVitalitasSpermaSebelum Dan SesudahDisimpanPadaSuhu $37^{\circ} \mathrm{C}$ Selama $1 \mathrm{Jam}$

\begin{tabular}{|c|c|c|}
\hline Kelompokperbandingan & $\begin{array}{c}\text { Vitalitassperma (\%) } \\
\text { SD }\end{array}$ & \multirow{2}{*}{ Nilaip } \\
\hline Sebelumperlakuan & $84,69 \pm 3,80$ & \multirow{2}{*}{0,000} \\
\hline Perlakuan & $70,00 \pm 4,15$ & \\
\hline
\end{tabular}

Tabel 4diatas esudahdisimpanpadasuhu $37^{\circ} \mathrm{C}$ selama 1 dataantaranilaivitalitasspermasebelumdans jam.

\section{PEMBAHASAN}

BerdasarkanujiKolmogorov

Smirnovhasil

yang

diperolehadalahpadakelompoksebelumperl akuan $p=0,987$ dankelompokperlakuan 1 diperoleh $p=0,975$, kelompokperlakuan 2 $\begin{array}{lll}\text { diperoleh } p & = & 0,982\end{array}$ danpadakelompokperlakuan 3 diperoleh $p$ $=0,938$. Nilaip $>0,05$ data berdistribusi normal.Karena data berdistribusi normal, makaujidilanjutkandengan $T$ -

Paired.DalamujiT-Paired hasilpemeriksaannilaivitalitasspermapadak elompoksebelumperlakuandibandingkande nganhasilpemeriksaanvitalitasspermapada masing-masingkelompokperlakuan, untukmelihatadaatautidakperbedaanantara keduakelompok data.

$$
\text { BerdasarkanujiT- }
$$

Paireddiperolehnilaiantaranilaivitalitasspe rmasebelumdan sesudahdisimpanpadasuhu $4^{\circ} \mathrm{C}$ selama 1 jam diperolehhasilsignifikandengannilaip $=0,000<\alpha=0,05$ (lampiran 6) 
berartiadaperbedaannilaivitalitasspermaseb

elumdansesudahdisimpanpadasuhu $\quad 4^{\circ} \mathrm{C}$ selama 1 jam.

Berdasarkanuji

T-

Paireddiperolehnilaiantaranilaivitalitasspe rmasebelumdansesudahdisimpanpadasuhu $25^{\circ} \mathrm{C} \quad$ selama $\quad 1 \quad$ jam diperolehhasilsignifikandengannilai $p=$ $0,000<\alpha=0,05 \quad$ (lampiran 6) berartiadaperbedaannilaivitalitasspermaseb elumdansesudahdisimpanpadasuhu $25^{\circ} \mathrm{C}$ selama 1 jam.

$$
\text { Berdasarkanuji T-Paired }
$$

diperolehnilaiantaranilaivitalitasspermaseb elumdansesudahdisimpanpadasuhu $37^{\circ} \mathrm{C}$ selama 1 jam diperolehnilai $p=0,000<\alpha=$ 0,05 (lampiran

berartiadaperbedaanhasilsignifikandengan nilaivitalitasspermasebelumdansesudahdisi mpanpadasuhu $37^{\circ} \mathrm{C}$ selama 1 jam.

\section{SIMPULAN DAN SARAN}

\section{Simpulan}

1. Nilaivitalitasspermasebelumperlakuany aitu $84,69 \%( \pm 3,80)$

2. Nilaivitalitassperma yang disimpanpadasuhu $\quad 4^{\circ}$ Cselama $\quad 1$ jamyaitu78,725\% $( \pm 3,809)$.

3. Nilaivitalitassperma yang disimpanpadasuhu $25^{\circ} \mathrm{C}$ selama 1 jam yaitu82,7875\% $( \pm 3,588)$.

4. Nilaivitalitassperma yang disimpanpadasuhu $37^{\circ} \mathrm{C}$ Selama 1 jam yaitu $70 \%( \pm 4,152)$.
5. Ada

perbedaansignifikanantaranilaivitalitass permasebelumdansesudahdisimpanpada suhu $4^{\circ} \mathrm{C}$ selama 1 jam

6. Ada

perbedaansignifikanantaranilaivitalitass permasebelumdansesudahdisimpanpada suhu $25^{\circ} \mathrm{C}$ selama 1 jam

7. Ada

perbedaansignifikanantaranilaivitalitass permasebelumdansesudahdisimpanpada suhu $37^{\circ} \mathrm{C}$ selama $1 \mathrm{jam}$

\section{Saran}

1. Kepadamasyarakat yang inginmelakukanpemeriksaansperma agar lebihmemperhatikansampelsperma yang akandibawakelaboratorium agar disimpanpadasuhu $25^{\circ} \mathrm{C}$ danmaksimalpenundaanpemeriksaanada lah 1 jam.

2. Kepadapihak-pihak yang inginmelakukanpenelitian yang serupa, diharapkanmelakukanpengembanganjen ispemeriksaansepertimotilitas, morfologidanhitungjumlahsperma.

\section{DAFTAR PUSTAKA}

1. Mohamed,Jamaludin, et al.2012.A Study of Sperm Quality Characteristics Changes in

Different Storage Temperatures above Freezing Point https://www.dropbox.com/s/qgarnrvvm ucp6xk/VIABILITAS.pdf?dl=0 diaksestanggal 20 November 2016. 
2. Cheesbrough,M. 2006. Laboratory Practice in Tropical Countries. Cambridge: Cambridge University Press.

3. Nilani.K, Eswaramohan.T, dan Balasubramaniam,K.2012. Influence of Temperature on Motility and Viability of Bovine Spermatozoa during Cold Storage. https://www.dropbox.com/s/2sznqa4bo vum2fe/ijsrp-p1254.pdf?dl=0 diaksestanggal 5 Juli 2017

4. Frankien,Daniel R. dan Oehniger,Sergio.2012.Semen analysis and sperm function testing.: https://www.dropbox.com/s/xgbgcywqf p9d3ea/Docfoc.comJurnal\%20Analisis\%20Sperma\%20$\%$ 20Analisis-spermatozoaAsia.pdf?dl=0.diakses tanggal 20 November 2016. 